\title{
THE
}

\section{Analysts' Forecasts, the Abandonment Option and Intellectual Capital}

Jeffrey E. Jarrett

University of Rhode Island, jejarrett133@outlook.com

Follow this and additional works at: https://digitalcommons.uri.edu/cba_facpubs

Creative Commons License

(c) (i)

This work is licensed under a Creative Commons Attribution 4.0 License.

\section{Citation/Publisher Attribution}

Jarrett, J. E. (2018). Analysts' Forecasts, the Abandonment Option and Intellectual Capital. International Journal of Accounting and Financial Reporting, 8(4), 370-383. doi: 10.5296/ijafr.v8i4.13825

Available at: https://doi.org/10.5296/ijafr.v8i4.13825

This Article is brought to you for free and open access by the College of Business at DigitalCommons@URI. It has been accepted for inclusion in College of Business Faculty Publications by an authorized administrator of DigitalCommons@URI.For more information, please contact digitalcommons-group@uri.edu. 


\title{
Analysts' Forecasts, the Abandonment Option and Intellectual Capital
}

\author{
Jeffrey E. Jarrett \\ Ph.D., College of Business, University of Rhode Island \\ Rhode Island, U.S. \\ E-mail: jejarrett@uri.edu
}

Received: October 26, 2018 Accepted: November 29, 2018 Published: December 2, 2018

doi:10.5296/ijafr.v8i4.13825

URL: https://doi.org/10.5296/ijafr.v8i4.13825

\begin{abstract}
The abandonment option under various capital budgeting models are discussed in this manuscript to bring forth the notion that present value of cash flows is often improperly estimated in the financial models utilized in the decision analytic process. In this study, Intellectual Property Rights and other intangible assets often are not considered in accounting estimation processes utilized in financial accounting. A decision maker often utilizes misestimates of the present value of cash flow resulting in less than optimum capital budgeting decisions. Decisions to abandon for salvage and other similar decisions improve when the present value of intangibles and property rights are included in the decision process. This last statement is the goal of this study and to present well founded processes to improve abandonment and similar decisions in capital budgeting decisions. The estimation problem in financial accounting is included in the analysis to accomplish this goal.
\end{abstract}

Keywords: Abandonment, Estimation theory, Present value of cash flow, Distribution of earnings, Opportunity loss

\section{Introduction}

In recent years, investors observed the importance of intellectual capital disclosure when making decision concerning the option to abandon projects that are expected to be unprofitable or undesirable The cause of these undesirable opportunities are often related to the value of intellectual and/or intangible capital. For example, Shareef and Davey (2005) studied the British Football industry which the major investments in this industry are human capital in the form PF players, coaches as well as management. The same is true of the football industry in the United States, Canady as well as other sports industries in the world. 


\section{$\triangle$ Macrothink}

International Journal of Accounting and Financial Reporting

ISSN 2162-3082

2018, Vol. 8, No. 4

The traditional accounting framework is largely ineffective in capturing these 'hidden' values often referred to as intangible values. We review in this study the research on the quality and extent to which intellectual capital is handle or not handled in the accounting literature underlying financial reporting of economic invents involving intangible and intellectual capital The research findings by Shareef and Davey indicated a positive and statistically significant relation between the size of clubs, club performance and their overall intellectual capital disclosure. This result was in line with other studies in other industries.

On the other hand, financial and accounting researchers such as Deschow (1994, and Deschow and Strand, 2004) indicated that employing accrual based accounting methods creates the capability of accounting based earnings projections to control and continuously improve the measures of firm performance reflected in analysts" earnings forecasts. The argument was that cash flow accuracy is expected to suffer from matching, realization and other timing problems concerning the timing the recognition of costs and revenues. Accuracy of financial earnings predictions was studied by (Brandon and Jarrett 1974; Jarrett and Khumawala, 1987; and Jarrett, 1983, 1992 and Lambert, Matolcsy and Wyatt, 2015). They compared methods of forecasting accounting earnings seeking to learn how forecast models can be compared and possibly improved to produce more accurate results as to cash flow. Questions posed included sources of accuracy but accrual accounting alone was not considered the most important source of inaccurate results. However, no one established a theoretical link between sources of inaccuracy and the matching principle and the accuracy of financial analysts' forecasts although many studied the problem [Jarrett, 1989, 1990, Clement, 1999, Gu and Wu, 2003, Ramnath, Rock and Shane, 2008; Grosyberg, Healy, Nohria and Serafeim, 2011]. Accounting reports containing these forecasts of cash flow and rates of return are in addition, subject to fluctuations in the interpretation of timing principles utilized by accountants. However, Gu and Wang (2005) brought up the possibility of another source of inaccuracy in the forecast of rates of return, cash flow and earnings. Beneish, Lee and Nichols, 2013) created a model that uses financial ratios calculated with accounting data of a specific company to check if it is likely that the reported earnings for a firm were manipulated the goal being to estimate earnings better in financial reports. Last, Lev and $\mathrm{Gu}$ (2016) in their study produced evidence from large-sample empirical analysis, that financial documents continuous deteriorate in relevance to investors' decisions. Further, they detail why accounting reporting is losing relevance in today's decisions related to capital budgeting and the abandonment option.

\section{The Purpose of This Study}

The study examines how the presence of the abandonment option uses normal capital budgeting methods to determine whether there is a relationship among the various capital budgeting options, financial leverage and estimating earnings by analysts. We begin by studying capital budgeting with the abandonment option; later most corporations use capital budgeting procedures to coordinate and motivate activities throughout their organization. It is well-understood that the budgeting process is dynamic and flexible, involving the information flow throughout the organization that determines the investment and abandonment decisions at the individual stages. We now examine at how an abandonment option influences the optimal 
timing of information and vice versa. In particular, we compare timely information, where the manager acquires perfect pre-contract project information. We examine how the future revenues from intangible assets may affect the level of financial leverage of a firm when not is all known about the economic value of intangible assets.

In the absence of the real option the following trade-off arises: If information is timely, the investment decision can be based on perfect information. Alternatively, if information about intangible assets is not considered in the abandonment option, the timing and decision concerning the abandon option may very well be estimated incorrectly. The incorrect $t$ information is the product of the misreporting of factual events associated with intangible assets and the error associated with incorrect analysts' forecasts turn to the estimation problem in financial accounting and in turn apply it to the relation of analysts' forecasts and the bias in estimating earnings and cash flow present in evaluating capital decisions.

\section{The Capital Budgeting Methodology}

Berger, Ofek and Swary (1996) established the link among analysts' forecasts, cash flow the expected capital asset pricing model (CAPM) return, and the present value of cash flow which includes forecasts of earning rather than the distributable cash flow. In addition, Wong (2009) examined the relation between the abandonment option's potential effect on a firm's decision analysis and the eventual analytics employed to determine the optimal decision and operating leverage. Furthermore, McDonald (2003) analyzed abandonment options, divestment options, expansion options and growth options previously examined in a survey by Triantis and Borison (2001). These and many more studies revealed that they use real options to the general problems associated with capital budgeting.

Analysts' earnings forecasts enable analysts to estimate the present value of cash flow (PVCF). According to Berger Ofek and Swary (1996), the advantage is that analysts' forecasts of earning do not incorporate the value of the abandonment option. If forecasts of distributable cash flows, cash flows from non-ongoing concern events would be included in the forecasts. Thus, earnings may not be the same as cash flows. Hence, we adjust because capital expenditures are not equivalent to depreciation and the growth in working capital is not subtracted from earnings. No longer is it required to adjust for capital structure changes in the environment that such changes cannot be foreseen. Borrowing again from Berger Ofek and Swary (1996), their equation constructs the PVCF evolves from the analyst's discounted forecasts. Included in the equation is the includes sum of the present value of analysts' predicted going-concern cash flows discounted by analyst forecast of year $t$ after-interest earnings and expected CAPM (capital asset pricing model return, consensus forecast of five year earnings growth, the terminal growth rate of earnings, the number of years for which earnings are forecast and a year index. The CAPM adjustment includes the reduction to the present value of analysts' earnings. The second adjustment to PVCF is the working capital adjustment which is a reduction to the present value of analysts' earnings forecasts to adjust for growth in working capital. Finally, the expected CAPM return is defined as 


$$
\mathrm{r}=\mathrm{rf}+\beta \mathrm{e}^{*}\left[\mathrm{r}_{\mathrm{m}}-\mathrm{rf}\right]
$$

where

$\mathrm{rf}=$ risk-free rate,

$\beta \mathrm{e}=$ the firm's beta or systematic risk (from the CRSP beta file),

$\left(\mathrm{r}_{\mathrm{m}}-\mathrm{rf}\right)=$ risk premium of the stock market minus the risk-free rate.

In implementing Eq. (1), we assume that the relevant investment horizon is short-term. Therefore, a useful solution is to use the one-month Treasury-bill-rate as a proxy for the risk-free. rate and a risk premium (the arithmetic mean from a long period of time from between the return on the S\&P 500 and the return on Treasury bills).

The problem with the above approach is the variable the analysts" forecasts of earnings. In part, this is a solution to the problems noted by Pappas (1977) in response by work by Brief and Owen (1968, 1969, 1970 and 1977, Barnea and Sadan, 1974, Jarrett (1983, 1992) who used their work in developing models to adjust analyst's' earnings forecasts in evaluating the abandonment option. Studies concerning analysts' forecasts are well known and include a huge number. In general, as stated by many others in the fields of financial accounting earnings forecasts are dependent on the principles of financial accounting which produces the data for modeling trends and seasonality (or modeling components). The accuracy of analysts' forecasts has a long history and includes by Clement, (1999) Gu and Wu (2003), Ramnath, Rock and Shane, (2008), Groysberg, Healy, Nohria and Serafeim (2011) and Makridakis, Spiliotis, and Assimakopoulos (2017). The last paper suggested that machine learning models may have better results than self-prepared models for forecasting. The aforementioned studies focused on a relationship between analysts' forecasts and the magnitude and value of intangible assets. Intangible assets were not considered in the forecasting method discussed by the researchers in their many and detailed studies. The value of intangible assets produces a great source of error if they are not considered in the forecasting methods utilized by analysts in the production of cash flow, rates of return earning per share (EPS) forecasts. When adjustments for intangible assets are included in the analyst's forecasts, Gu and Wang (2005 p. 673) stated that "The rise of intangible assets in size and contribution to corporate growth over the last two decades poses an interesting dilemma for analysts. Most intangible assets are not recognized in financial statement, and current accounting rules do not require firms to report separate measures for intangibles." Intangibles include trademarks, brand names, patents and similar properties that have value but are generally not listed in the financial reports of firms. Many of these items are technology based and are very important in financial decisions such as in mergers and acquisitions. They are an intricate in the growth of firms and therefore are shown to be related in the statistical sense to the overall estimates made by accounting and analysts.

In another study concerning analysts' forecasts, Matolcsy and Wyatt (2006) found that the association between EPS forecast, growth rates forecast error and measures of technological conditions in the firm's industry. They found that as the forecast horizon increases, the technological conditions and current EPS are statistically associated with analysts' forecasts. 
Long horizon creates the conditions for within one to conclude that interactions between technological conditions and current EPS are associated with analysts' EPS and growth forecasts. This conclusion align itself with Jung, Shane and Yang (2012) who suggested that analysts' growth forecasts effect efforts to evaluate analysts' forecasts may produce optimistically biased long-term forecasts. Because intangible assets that are often technology based are taken up more of the balance sheet of many firms, it is likely that analyst's forecasts may produce less accurate predictions of earnings, cash flow and rate of return. The conclusions of Dechow (1994) become less important. Balance sheets usually have little or no involvement with the value of intangibles although there are some practices by accounting are still used. Thus in the remaining portions of this analysis, we propose a method by which one can estimate earnings such that the value of intangible assets is valued and earnings estimate are not biased by serious errors of omission such that the capital budgeting model expressed earlier in equations by Berger, Olek, and Swary (1996, p. 264) are not unduly biased.

\section{Intellectual Property and Traditional Accounting Methodology}

As noted by [Brief and Owen 1969, 1970, 1977; Jarrett, 1971, 1974, and 1983; Roberts and Roberts, 1970; and Barnea and Sadan, 1974;] the timing of recognition of revenue for intellectual property rights IPR in financial statements of ten are not featured in merger and acquisition activity. The Financial Accounting Standards Board (FASB) provides for such activities, however, they are often ignored due to their evasiveness or are not fully informational in the normally structured rules. Recognizing future performance is a goal of matching and timing but are unrelated to recognizing cash flow and similar items in the historical performance of a firm. Non-profit entities often do not use accrual rules at all because the goal of these are related to achieving high rates of return. Often IPR for non-profits would differ from the same item for profit maximizing entities because the goal of seeking high rates of return does not enter the strategic planning process for non-profits \{World Trade Organization, 2016\}. The purpose here is to consider IPR as intangible assets as a product of intellect that law protects from unauthorized use by those not responsible for the IPR. Hence, IPR are characterized as the protection of distinguished signs such as trademarks for goods and services, patents, and other similar items that are under protection from unauthorized use. This includes art, music, creations by authors including the authorship of computer software and similar items such as discoveries, inventions, phrases, symbols and design. Obviously, a writer and conductor of music such as Leonard Bernstein and Daniel Barenboim would have created IP that differ greatly from physicists such as Lise Meitner, Nils Bohr or Albert Einstein.

Presently, accounting suggests two methods to determine the value of IPR to produce better estimates of from accounting analysts' forecasts. The convention of the "lower of cost or market" is based on the rule of conservatism in valuing assets to anticipate future losses instead of future gains. The policy tens to understate rather than overstate the value of net assets and could therefore lead to an understatement of income, cash flow, earnings and rates of return. The purpose of this study and its conclusive result is to neither understate nor overstate cash flow so as to produce a rate of return on cash flow that is commensurate with the goal of producing accurate prediction of cash flow and its rate of return for financial and decision making purposes. Stated differently, the purpose is not to violate accounting policy but ensure 
the (M\&A) that cash flow is estimated properly. Traditionally, when accounting writes policy about intangible assets as a residual, by "residual," they mean a buyer is ready to value a firm in excess of the value of the tangible assets. This value is often referred as "goodwill" (White, Sandhi, and Fried, 1994) which is an imperfect method. This notion of goodwill is estimated as a residual value. If the valuation of intangible property is imperfect since it considers part of the solution of a bargaining process. In this case, the buyer and seller may have different market power which greatly affects the residual of the bargaining process and produces an imperfect or biased estimate of the value of the intangible assets. One may examine the case of the sale of "Superman" by struggling comic book artists to a much larger corporate power who could market the character to "comic books", television and the film Industry. The nearly destitute conditions of the original artists who created the intangible product could never cope with the business and marketing (power) of those who purchased the name "Superman." Thus, goodwill becomes a vague valuation system that justifies the bringing of data analysis and science into the valuation process.

Another solution suggested during the M\&A process is to simply list the patents, trademarks, brands and similar items of IP in the financial reporting of the firm. Following this initiative and suggestion of the accounting principles board provide little aid concerning the economic value of IPR and products for a firm during the M\&A events. In the final step of the problem the evaluation may conclude influence relating to the biases of the reading of the financial reports. Such biases of IPR occurred often with works of Meitner, Einstein and Bohr. Whereas, at least Einstein and Bohr received Nobel Prizes which did have wealth, but Meitner perhaps due to her gender and religious preference never received the award the others were given. Symphony conductors and composers of music there was no economic award from the Nobel Prize Committees. Accountants forecast the overall rate of return for a firm but do not ignore the convention of "conservatism." Accounting practice values the IPR for a firm each year for each and every IPR under consideration. The principle of Goodwill is not to be used during M\&A activity to account for the value of IPR. IP may induce greater asset values but also affects the rate of return on cash flow because the denominator of the rate of return will change. [To understand the gravity of ignoring or improperly valuing IPR see Jarrett, 2016, 2017a and 2017b]. This result debated previously (Brief and Owen, 1969; Brief, 1977, and Pappas, 1977) indicated that including earnings risk may not fully reflect all risk in estimating earnings, but at least, reflects that part of risk from the variation in earnings.

Furthermore, Helliar, Lonie, Power and Sinclair (2001) summarized attitudes of managers toward risk in the following way. The abandonment option may be extremely important when considering the survival of a firm or non-profit entity. Survival is often the goal of the abandonment option indicating that risks that are taken in special situations such as catastrophes when the survival of whole areas of an industry may be under threat (Shleifer and Vishny, 1992, and Liu and Liu, 2011) may be different from those taken in more usual environments. An entity in decline may avoid innovative options and concentrate on immediate short-term options rather than riskier longer-term projects with more difficult goals to be accomplished. In addition, the choice may rapidly increase the rate upward of the process 
decline and result in managers becoming more risk averse and not employing greater use of intangible assets and intellectual property.

\section{Earnings Estimation Including the Estimation and Monetary Values for Intangible} Assets

In this section we illustrate the size of the bias in estimating earnings when the monetary equivalent of values of intangible assets not considered by analysts in estimating future earnings. Note, misestimating future earnings affects PVCF resulting in errors in assessing the abandonment option. Intangible assets including patents, trademarks, copyrights and similar items are usually overlooked and/or not estimated properly in many financial statements. These statements are considered fundamental information is determining PVCF in abandonment decisions, mergers, acquisitions and similar financial decision analysis and analytics.

To illustrate the case of monetarizing property rights and other intangibles often referred to by the acronym IPR, let us consider the specific problem of a firm abandoning or selling IPR through a direct acquisition and the effect on debt as part of its holdings. Obviously, the ratio of common equity to total capital stock will be changed during the financial operation. In turn, the effects of financial leverage on total financial risk will also be part of the problem. The rate of return to common shareholders is related to the measure of financial risk utilized in any decision of this type. We assume that the firm is motivated is finance the acquisition by leverage instead of issuing new common share nor a strict loan from a financial institution or similar institution is the result of an economic optimization policy. Define $\mathrm{T}$ as the sum of debt and common stock. To illustrate simply, preferred share and other financial instruments are valued at zero to avoid complications that my hinder the explanation. $\mathrm{S}$ is the monetary value of outstanding common and $\mathrm{D}$ is amount oi debt; $\mathrm{X}$ the amount of earning in a future time period. $\mathrm{X}$ is a random variable and $\mathrm{E}(\mathrm{X})$ is the mean of the random variable, $\mathrm{V}(\mathrm{X})$ the variance and $S(X)$ the square root or standard deviation. The cost of the debt per dollar is I; the interest rate. The mean earning per dollar of $\mathrm{S}$ is

$$
\mathrm{E}(\mathrm{Y})=\mathrm{E}(\mathrm{X}) / \mathrm{S}=\mathrm{E}(\mathrm{X}) /(\mathrm{T}-\mathrm{D})
$$

Note that $\mathrm{Y}$ is also a random variable with mean $\mathrm{E}(\mathrm{Y})$. Mean (or expected) earning is defined as follows:

$$
\begin{gathered}
E\left(X^{\prime}\right)=E(X)-i D \text { for } D>0 \\
\text { Hence, } E\left(X^{\prime}\right)=E(X) \text {, for } D=0
\end{gathered}
$$

The variance of total earnings is

$$
\mathrm{V}\left(\mathrm{X}^{\prime}\right)=\mathrm{V}(\mathrm{X}) \text { for } \mathrm{D} \geq 0 \text { (iD and is a constant) }
$$

The financial decision-optimum is to fund the purchase is an example of decision analytics where the decisions are to substitute debt for common stock or not to substitute debt. Using data analytical language, for this decision problem the states of nature are defined by

$$
\mathrm{E}(\mathrm{X})>\mathrm{ID} \text { or } \mathrm{E}(\mathrm{X}) \leq \mathrm{ID}
$$




\section{MlMacrothink}

International Journal of Accounting and Financial Reporting ISSN 2162-3082

We define the opportunity loss function as an integral approximation the firm's view towards choosing a non-optimal decision. No loss occurs when earnings are great than the cost of debt since management will benefit from the strategy of leverage financing.

As an example consider cash flow to be greater than the cost of debt management and in turn the loss function would change reflecting the goal of optimum decision analytics. The basic structure of the acquisition strategy would not change except for the substitution of cash flow for earnings. To calculate the opportunity loss function associated with this strategy, we estimate some probability density function (PDF) that approximates the PDF for future earnings. Before we consider all PDFs, let the firm focus on the normal distribution or T-distribution having a very large number of degrees of freedom which approximates the standard normal distribution. The opportunity loss becomes at breakeven $\left(\mathrm{X}_{\mathrm{b}}\right)$ becomes

$$
\mathrm{X}_{\mathrm{b}}=\mathrm{E}\left(\mathrm{X}^{\prime}\right)-\mathrm{Z}\left(\left(\mathrm{S}\left(\mathrm{X}^{\prime}\right)\right)\right.
$$

$\mathrm{Z}$ refers to the normal fiducial deviate; and $\mathrm{S}\left(\mathrm{X}^{\prime}\right)$ the standard deviation. By rearrangement, we find $E(X)=E\left(X^{\prime}\right)-i D$. The next step is to determine the size and distribution of the loss function for the distribution of future earnings which is all in line with objectives of the timing of the realization revenues discussed before Jarrett $(1971,1992)$. In Table 1 we preview one of three methods to estimate the monetary value of IPR. The $E(X)$ is $\$ 4200$ and the $S(X)$ increases by given amounts $(\$ 100)$. Column 3 contains the cost of debt of $\$ 3200$. The $\mathrm{Z}$ (the normal deviate) calculation is accomplished column 4 with column 5 containing the cumulative normal probability. In turn, the IPR monetary value is simply the normal probability multiplied by $\mathrm{E}(\mathrm{X})$ and is contained in column 6 . The IPR $\$$ is thus calculated for a variety of circumstances.

Table 1. Monetarization of IPR with changes in standard deviation of earnings

\begin{tabular}{llllll}
\hline $\mathbf{E}(\mathbf{X})$ & $\mathbf{S}(\mathbf{X})$ & Cost of Debt & $\mathbf{Z}-$ Score & Cum. Prob. & \$IPR \\
\hline 4200 & 400 & 3200 & 2.50000 & 0.993790 & 4174 \\
\hline 4200 & 500 & 3200 & 2.00000 & 0.977250 & 4104 \\
\hline 4200 & 600 & 3200 & 1.66667 & 0.952210 & 3999 \\
\hline 4200 & 700 & 3200 & 1.42857 & 0.923436 & 3878 \\
\hline 4200 & 800 & 3200 & 1.25000 & 0.894350 & 3756 \\
\hline 4200 & 900 & 3200 & 1.11111 & 0.866740 & 3640 \\
\hline 4200 & 1000 & 3200 & 1.00000 & 0.841345 & 3534 \\
\hline
\end{tabular}


A second example of estimating the monetary value of IPR (Table 2, E(X), column 1 is constant from row to row, column 2, S(X), remains the same (\$600) from row to row and column 3 the cost of debt changes from row to row due to the change in the interest rate and other costs associated with debt. Column 4 , the standard normal deviate, $\mathrm{Z}$, decreases in value from row to row and column 5, the cumulative probability from the normal curve decreases from row to row. The dollar value of the IPR will continually decrease from the top row to the bottom row in Table 2.

Table 2. IPR monetarization with changes in interest rates and cost of debt

\begin{tabular}{llllll}
\hline $\mathbf{E}(\mathbf{X})$ & $\mathbf{S}(\mathbf{X})$ & Debt Cost & $\mathbf{Z}$ & Normal Probability & \$IPR \\
\hline 2100 & 600 & 500 & 2.66667 & 0.996170 & 2091.96 \\
\hline 2100 & 600 & 1200 & 1.50000 & 0.933193 & 1959.70 \\
\hline 2100 & 600 & 1400 & 1.16667 & 0.878327 & 1844.49 \\
\hline 2100 & 600 & 1600 & 0.83333 & 0.797672 & 1675.11 \\
\hline 2100 & 600 & 1800 & 0.50000 & 0.691462 & 1452.07 \\
\hline 2100 & 600 & 2000 & 0.16667 & 0.566184 & 1188.99
\end{tabular}

One last example, Table 3, we alter the example by comparing the monetary value of IPR when the cost of debt and debt: equity ratio in columns 1 and 2 of Table 3 change. In turn both columns 3 and 4 change (cost of debt and net cash) change from row to row. The Z-statistics and normal probabilities change and the monetary value of IPR changes from row to row with the highest in row 1 and descending thereafter.

Table 3. Monetary equivalent vs. capital structure (equity $=\$ 200000$ )

\begin{tabular}{llllllll}
\hline Debt & D:E ratio & $\begin{array}{l}\text { Debt } \\
\text { Cost }\end{array}$ & $\begin{array}{l}\text { Cash } \\
\text { Inflow }\end{array}$ & $\mathrm{S}(\mathrm{X})$ & $\mathrm{Z}$ & $\begin{array}{l}\text { Normal } \\
\text { prob. }\end{array}$ & $\$ I P R$ \\
\hline 50000 & 0.25 & 2000 & 2300 & 230 & 1.304 & 0.903942 & 180788 \\
\hline 60000 & 0.30 & 2400 & 1900 & 190 & -2.632 & 0.004249 & 850 \\
\hline 70000 & 0.35 & 2800 & 1500 & 150 & -8.667 & 0.000000 & 0 \\
\hline 80000 & 0.40 & 3200 & 1100 & 110 & -19.091 & 0.000000 & 0 \\
\hline 90000 & 0.45 & 3600 & 700 & 70 & -41.429 & 0.000000 & 0 \\
\hline
\end{tabular}




\section{Mll Macrothink}

International Journal of Accounting and Financial Reporting

ISSN 2162-3082

2018, Vol. 8, No. 4

In summary, three sets of examples demonstrate that estimation theory in financial accounting is a fundament portion of correcting financial reporting data such that analysts now have a complete set of data work with when making earnings forecasts and other decisions. Our finding does not dispute that of others.

\section{Additional Evidence Concerning Estimation Theory and Methods}

Estimation and timing of the recognition and matching of costs and revenues is dependent on the underlying analysis of data that corroborates its use. Although, one cannot examine all data but samples of data analyzed previously by Berger et al. (1996). In their study, they obtained data from the International Brokers Estimate System (IBES) that have forecasts of earnings and growth in earnings. In Table 4, we provide their descriptive information on the sample information obtained. The information obtained describe the distribution of PVCF for three separate forecast methods. In analyzing these data, we calculated the skewness coefficient and presented the results of in the expanded table. The analytics indicates the symmetry in the distributions of the PVCF data.

Table 4. Distributions of PVCF from Berger, et. al. (1996, p.269)

\begin{tabular}{|c|c|c|c|c|c|c|}
\hline \multirow[t]{2}{*}{ Data from IBES } & \multirow{2}{*}{$\begin{array}{l}\text { Sample } \\
\text { Minimum }\end{array}$} & \multicolumn{5}{|c|}{ Studies By Berger et. al. } \\
\hline & & Median & Mean & Maximum & Std. Dev. & Skewness \\
\hline $\begin{array}{l}\text { PVCF from } \\
\text { Forecast/ETF }\end{array}$ & -0.645 & 0.128 & 0.144 & 0.622 & 0.08 & 0.200 \\
\hline $\begin{array}{l}\text { PVCF } \\
\text { Growth }\end{array}$ & 0.037 & 0.42 & 0.413 & 1.161 & 0.086 & -0.081 \\
\hline $\begin{array}{l}\text { PVCF from } \\
\text { Terminal Growth }\end{array}$ & 0.084 & 0.437 & 0.443 & 1.521 & 0.12 & 0.050 \\
\hline
\end{tabular}

Note: If skewness is positive, the data are positively skewed or skewed right, meaning that the right tail of the distribution is longer than the left. If skewness is negative, the data are negatively skewed or skewed left, meaning that the left tail is longer. If skewness $=0$, the data are perfectly symmetrical.

Any threshold or rule of the thumb is arbitrary, but here is one: if the skewness is greater than 1.0 (or less than -0.1), the skewness is substantial and the distribution is fat from summetrical.

As we see from Table 4, the distribution of the sample data is probably very close to symmetrical and, in turn, likely to be distributed similar to a normal distribution process. If not exactly normally distributed, there are many ways one can estimate the distribution of the PVCF data bringing more credibility to the process. One last point concerning the distribution of PVCF in Table 4 concerns the kurtosis in the sample data summarized above. Westfall 
(2014) notes, it's only unambiguous interpretation is in terms of tail extremity; i.e., either existing outliers (for the sample kurtosis) or propensity to produce outliers (for the kurtosis of a probability distribution). The logic is simple: Kurtosis is the average (or expected value) of the standardized data raised to the fourth power. Any standardized values that are less than 1 (i.e., data within one standard deviation of the mean, where the "peak" would be), contribute virtually nothing to kurtosis, because raising a number that is less than 1 to the fourth power makes it closer to zero. The only data values (observed or observable) that contribute to kurtosis in any meaningful way are those outside the region of the peak that is the outliers. Therefore, kurtosis measures outliers only; it measures nothing about the "peak. Without the original data, one cannot measure the exact Kurtoses for the data. However, one can observe that the mean of data and minimum and maximum values do not differ by huge amounts. Hence, the exact likelihood of long tails in the distribution of data about the mean do not exists. The likelihood is therefore, such an observation indicates that if at all, the measures of kurtoses would be relative small and approach a normal distribution when examining the population from which the sample was chosen. Hence, the normal approximation when the sample size is large as in the cases observed indicates the validity of the normal approximation. This is also the case if one has evidence that the data is distributed according to another probability distribution function and that one could be used in evaluating the value of IPR.

\section{Summary and Conclusion}

Firms entering into decisions in times of financial distress are often confronted with failure and survival. These decisions concern the abandonment of assets. The problems associated with valuing intangible assets and IPR are similar to those involved in decisions about M\&A. The firm's environment may different in each case, however the problems associated with predicting cash flow and earnings by analysts still prevail. This study suggests ways of estimating the earning and PVCF when considering the effects of IPR and other intangible assets in the process. The proposal studied meets the requirements of the estimation theory in financial account which is consistent with accounting conservatism and goals of financial accounting. Additional methods exist for estimating the value of intangibles which include using the distribution of financial earnings when the normal distribution does not apply. This will be the focus of new and additional research.

\section{References}

Barnea, A., \& Sadan, S. (1974). On the Decomposition of the Estimation Problem in Financial Accounting. Journal of Accounting Research, 12, 197-203.

Beneish, M. D., Lee, C. M. C., \& Nichols, D. C. (2013, March/April). Earning Manipulation and Expected Returns. Financial Analysts Journal, 57-82.

Berger, P. G., Ofek, E., \& Swary, I. (1996). Investor valuation of the abandonment option. Journal of Financial Economics, 42, 257-287.

Brandon, C., \& Jarrett, J. E. (1974). Accuracy of Financial Forecasts. The Financial Review, 9, 29-45. 


\section{Macrothink}

International Journal of Accounting and Financial Reporting

ISSN 2162-3082

2018, Vol. 8, No. 4

Brief, R. (1977). A Note on the Inclusion of Earnings Risk in Measures of Return: A Reply. Journal of Finance, 32, 1367.

Brief, R., \& Owen, J. (1968). A Least Squares Allocation Model. Journal of Accounting Research, 6(2), 193-199.

Brief, R., \& Owen, J. (1969). A Note on Earnings Risk and the Coefficient of Variation. Journal of Finance, 24(4), 901-904.

Brief, R., \& Owen, J. (1970). The Estimation Problem in Financial Accounting. Journal of Accounting Research, 8, 167-177.

Clement, M. B. (1999). Analyst forecast accuracy: Do ability, resources, and portfolio complexity matter?. Journal of Accounting and Economics, 27(3), 285-303.

Deschow, P. M. (1994). Accounting earnings and cash flows as measures of firm performance: The Role of accounting accruals. Journal of Accounting \& Economics, 18, 3-42.

Deschow, P. M., \& Schrand, C. M. (2004). Earnings Quality. Research Foundation Books, 3, $1-152$.

Gordon, M., \& Halpern, A. (1974). Cost of Capital for a Division of a Firm. Journal of Finance, 29, 1153-1163.

Groysberg, B., Healy, P., Nohria, N., \& Serafeim, G. (2011). What factors drive analyst forecasts?. Financial Analysts Journal, 67(4), 18-29.

Gu, F., \& Wang, W. (2005). Intangible Assets, Information Complexity and Analysts Earnings Forecasts. Journal of Business Finance and Accounting, 32(9-10), 1673-1702.

Gu, Z., \& Wu, J. S. (2003). Earnings skewness and analyst forecast bias. Journal of Accounting and Economics, 35(1), 5-29.

Helliar, C., Lonie, A., Power, D., \& Sinclair, D. (2001). Attitudes of UK Managers to Risk and Uncertainty. Balance Sheet, 9, 7-10.

Jarrett, J. E. (1971). The Principles of Matching and Realization as Estimation Problems. Journal of Accounting Research, 9, 378-382.

Jarrett, J. E. (1974). Bias in Adjusting Asset values for Changes in the Price Level: An Application of Estimation Theory. Journal of Accounting Research, 12, 63-66.

Jarrett, J. E. (1983). The Rate of Return from Interim Financial Reports. Journal of Business Finance and Accounting, 10, 289-294.

Jarrett, J. E. (1989). Forecasting monthly earnings per share--Time Series Model. OMEGA: The International Journal of Management Science, 17, 37-44.

Jarrett, J. E. (1990). Forecasting Seasonal Time Series of Corporate Earnings: A Note. Decisions Sciences, 21(4), 888-893. 


\section{$\triangle 1$ Macrothink}

International Journal of Accounting and Financial Reporting

ISSN 2162-3082

2018, Vol. 8, No. 4

Jarrett, J. E. (1992). An Economical Method for Correcting Forecasting Error. American Journal of Business, 7, 55-58.

Jarrett, J. E. (2016). The Problems of Accounting Reporting False Information and Estimation. Intellectual Property Rights, S1(007).

Jarrett, J. E. (2017a). Intellectual Property Valuation and Accounting. Intellectual Property Rights, 5, 181.

Jarrett, J. E. (2017b). Intellectual Property and the Role of Estimation in Financial Accounting and Mergers and Acquisitions. SF Journal of Intellectual Property Rights, 1(1), 1-8.

Jarrett, J. E., \& Khumawala, S. (1987). A Study of Forecast Error and Covariant Time Series to Improve Forecasting for Financial Decision Making. Managerial Finance, 13, 20-24.

Jung, B., Shane, F., \& Yang, Y. (2012). Do Financial Analysts' Long-Term Growth Forecasts Matter? Evidence from Stock Recommendations and Career Outcomes. Journal of Accounting \& Economics, 51, 1-2.

Lambert, D., Matolcsy, Z., \& Wyatt, A. (2015). Analysts' earnings forecasts and technological conditions in the firm's investment environment. Journal of Contemporary Accounting and Economics, 11, 1-46.

Lev, B., \& Gu, F. (2016). The End of Accounting and the Path Forward for Investors and Managers. Wiley.

Liu, P., \& Liu, C. H. (2011). The quality of real assets, liquidation value and debt capacity. The Center for Real Estate and Finance Working Paper Series, 2010-009, 1-43.

Makridakis, S., Spiliotis, E., \& Assimakopoulos, V. (2017). The Accuracy of Machine Learning (ML) Forecasting Methods versus Statistical Ones: Extending the Results of the M\#-Competition. Working Paper, University of Nicosia, Institute for the Future, Greece.

Matolcsy, Z., \& Wyatt, A. (2006). Capitalized intangibles and financial analysis. Accounting and Finance, 46, 457-479.

McDonald, T. (2003). Review of environmental monitoring methods: Survey Designs. Environmental Monitoring and Assessment, 85, 277-292.

Pappas, J. L. (1977). A Note on the Inclusions of Earnings Risk in Measures of Return: A Comment. Journal of Finance, 32, 1363-1366.

Ramnath, S., Rock, S., \& Shane, P. B. (2008). The financial analyst forecasting literature: A taxonomy with suggestions for further research. International Journal of Forecasting, 24, 34-75.

Roberts, C., \& Roberts, E. (1970). Exact Determination of Earnings Risk by the Coefficient of Variation. Journal of Finance, 25, 1161-1165.

Romanna, K., \& Watts, R. L. (2012). Evidence on the use of unverifiable estimates in required goodwill impairment. Review of Accounting Studies, 17, 749-780. 


\section{Macrothink}

International Journal of Accounting and Financial Reporting ISSN 2162-3082 2018, Vol. 8, No. 4

Schliefer, A., \& Vishnay, R. W. (1992). Liquidation Values and Debt Capacity: Market Equilibrium Approach. Journal of Finance, XLVII(4), 1343-1366.

Shareef, S., \& Davey, H. (2005). Accounting for intellectual capital: Evidence from listed English football clubs. Journal of Applied Accounting Research, 7(3), 78-116

Triantis, A., \& Borison, A. (2001). Real Options: State of the practice. Journal of Applied Corporate Finance, 14(2), 8-24.

Westfall, P. H. (2014). Kurtosis as Peakedness, 1905 - 2014. R.I.P. The American Statistician, 68, 191-195.

White, G. I., Sandhi, A. C., \& Fried, D. (1994). The Analysis and Uses of Financial Statements (3rd ed.). John Wiley, New York.

Wong, K. P. (2009). The effects of abandonment options on operating leverage and investment timing. International Review of Economics \& Finance, 18(1), 162-171.

WTO. (2016). What are intellectual property rights?. World Trade Organization.

\section{Copyright Disclaimer}

Copyright for this article is retained by the author(s), with first publication rights granted to the journal.

This is an open-access article distributed under the terms and conditions of the Creative Commons Attribution license (http://creativecommons.org/licenses/by/4.0/) 